\title{
Characterization of morphology and angiogenesis in follicles of mares during spring transition and the breeding season
}

\author{
E. D. Watson and M. O. Al-zi'abi \\ Department of Veterinary Clinical Studies, University of Edinburgh, \\ Easter Bush, Midlothian EH25 9RG, UK
}

The mare is a seasonal breeder and undergoes a period of ovarian transition in spring between winter anoestrus and cyclicity. During spring transition LH concentrations are low and many mares have successive large anovulatory follicular waves which reach the size of preovulatory follicles. Follicular angiogenesis is essential for growth and health of preovulatory follicles. The aim of the present study was to investigate the morphology and vascularity of transitional anovulatory follicles. On gross inspection, the wall of transitional follicles was visibly less well vascularized than that of preovulatory follicles. Histologically, it could be seen that the theca was only poorly developed in transitional follicles. Immunostaining for factor VIII showed that there were significantly $(P<0.05)$ fewer blood vessels in the theca of transitional follicles. There was substantially less $(P<0.001)$ proliferative activity, measured by immunostaining for Ki67, in the endothelial cells and granulosa cells of transitional follicles compared with preovulatory follicles. Preovulatory follicles had a heavy band of immunostaining in the theca for vascular endothelial growth factor (VEGF), whereas staining was sparse in the transitional follicles. It was concluded that the poor vascularity and development of the theca layer in transitional follicles could be related to low circulating LH, and possibly other trophic hormones, and are likely to be the key factors in explaining the steroidogenic incompetence of transitional anovulatory follicles.

\section{Introduction}

The mare is a seasonal breeder and most mares enter a period of anoestrus during the short days of winter. During this time only very small follicles are present in the ovaries. In many mares there is a transitional period between deep winter anoestrus and normal ovarian cyclicity, when larger follicles grow and regress. In approximately $50 \%$ of mares, sequential anovulatory follicular waves then develop, with the dominant follicle reaching a diameter similar to that of a preovulatory follicle (Ginther, 1990). These follicles fail to ovulate because of suppression of $\mathrm{GnRH}$ secretion by inhibitory neuronal mechanisms that results in lack of LH stimulation (Fitzgerald and Mellbye, 1988; Aurich et al., 2000). Furthermore, these large transitional follicles are thought to be steroidogenically incompetent as circulating oestradiol concentrations are very low, and incubated granulosa cells from anovulatory transitional follicles produce significantly lower concentrations of oestradiol than do granulosa cells from preovulatory follicles (Davis and Sharp, 1991).

As daylength increases, an increase in GnRH secretion results in FSH secretion and follicle growth (Freedman et al., 1979; Turner et al., 1979). LH secretion does not increase as pituitary reserves are low in winter (Silvia et al., 1987). However, shortly before first ovulation there is a large increase in circulating $\mathrm{LH}$ which coincides temporally with

Email: elaine.watson@ed.ac.uk an increase in plasma oestrogen concentrations. It is thought that the increase in circulating oestradiol is the key event in increasing LH synthesis or secretion or both at the pituitary, or in increasing GnRH release (Sharp et al., 1991). The reason for the apparently low steroidogenic capacity of transitional follicles is unclear. There is significant in vitro conversion of labelled androstenedione to oestrogens by transitional follicles (Seamans and Sharp, 1982) and so it appears that these follicles have sufficient quantities of the aromatizing enzyme, $\mathrm{P} 450_{\mathrm{arom}}$. There is circumstantial evidence that the rate-limiting step in oestrogen synthesis in transitional follicles may be insufficient amounts of androgen substrate caused by low amounts of $\mathrm{P} 450 \mathrm{C} 17$. Concentrations of progesterone were similar in large follicles throughout transition and into cyclicity, but concentrations of androgen did not increase until the onset of cyclicity (Davis and Sharp, 1991). Although there may be deficiencies in steroidogenic enzymes in transitional follicles, an alternative explanation may be that the development of the transitional follicles is not as advanced as that of preovulatory follicles, and they may be less well endowed with blood vessels, thus limiting availability of substrate for steroidogenesis. Indeed, there is anecdotal evidence that, on gross inspection, transitional follicles appear to be relatively avascular (Sharp and Davis, 1993).

The regulatory role of gonadotrophins in follicle development has been well documented; however, the mechanisms acting locally within the follicle that translate hormonal stimulation into growth and differentiation are 
not well understood. Blood vessel development has a crucial role in follicular maturation (Richards, 1980) and, during follicle growth, a rich capillary plexus develops in the thecal layer surrounding the avascular granulosa cells. Studies in primates have shown that the density of the microvascular network of follicles destined to ovulate is at least double that of follicles destined to become atretic (Zeleznik et al., 1981). This increased vascularity results in increased delivery of gonadotrophins to preovulatory follicles. Ravindranath et al. (1992) showed that there is an apparent association between the capacity of a follicle to produce angiogenic factors and follicle selection. Angiogenesis requires proliferation and migration of vascular endothelial cells. Several intraovarian regulators have been implicated in angiogenesis. Vascular endothelial growth factor (VEGF) is a multifunctional cytokine that stimulates blood vessel formation and enhances microvascular permeability with 50000 times the potency of histamine (Dvorak et al., 1995). Expression of VEGF mRNA and protein has been reported in follicles and corpora lutea of various species (Ravindranath et al., 1992; Gordon et al., 1996; Yamamoto et al., 1997; Barboni et al., 2000; Toutges et al., 2000; Kashida et al., 2001). There appears to be a clear difference in patterns of expression among species.

Very little is known about the relative vascularity of equine ovulatory and anovulatory transitional follicles, although it is clear that the degree of vascularization may be a critical factor in determining their subsequent fate. Therefore, in the present study we used immunohistochemistry to detect the presence of VEGF in transitional and preovulatory follicles. The proliferative activity in granulosa cells and endothelial cells was investigated by determining expression of the Ki67 antigen, and the distribution and neoformation of blood vessels was confirmed by immunolocalization of the endothelial cell marker, Von Willebrand factor VIII.

\section{Materials and Methods}

Six pony mares of mixed breeding, weighing 344-445 kg and aged 3-19 years, were used. The reproductive history of the mares was unknown, but all were in winter anoestrus at the beginning of the period of study. The ovaries of the mares were examined three times a week by transrectal ultrasonography from the beginning of February until the onset of follicular waves. During one of the follicular waves, the ovary containing the dominant follicle was removed by a colpotomy incision after appropriate sedation and analgesia (Watson and Sertich, 1990) on the day after the dominant follicle reached $30 \mathrm{~mm}$ in diameter. The mares were then monitored by transrectal ultrasonography until first ovulation, which occurred between 13 April and 10 May. The remaining ovary was removed at either the second or third subsequent oestrus on the day after the dominant follicle reached $30 \mathrm{~mm}$ in diameter. Care was taken to remove ovaries only when the diameter of the follicle was increasing each day.
Immediately after ovariectomy, excized ovaries were transported on ice to the laboratory for dissection. After identification of the largest follicle, the tunica albuginea was removed carefully with fine scissors and forceps, and the follicle diameter was measured and recorded. A syringe and fine gauge needle were used to aspirate follicular fluid, which was stored at $-20^{\circ} \mathrm{C}$ until assayed for oestradiol. The follicle was re-inflated with air and the anterior follicle wall was cut open. The appearance of the follicle wall was recorded. One piece of follicle wall, approximately $0.5 \mathrm{~cm} \times 0.5 \mathrm{~cm}$, was immersed in freshly prepared $4 \%$ $(\mathrm{w} / \mathrm{v})$ paraformaldehyde. The tissue was kept at $4^{\circ} \mathrm{C}$ and transferred $24 \mathrm{~h}$ later to $70 \%(\mathrm{v} / \mathrm{v})$ alcohol until it was embedded in paraffin wax.

\section{Immunostaining}

Immunostaining was performed using the following antibodies: rabbit anti-VEGF (Santa Cruz Biotechnology, Santa Cruz, CA), rabbit anti-human Von Willebrand factor VIII (Dako Laboratories, High Wycombe) and a monoclonal antibody directed against the nuclear non-histone antigen, Ki67 (Novocastra, Peterborough). Paraffin wax sections ( $4 \mu \mathrm{m}$ thickness) were mounted on slides coated with BioBond (British Biocell Int., Cardiff), deparaffinized and rehydrated. The sections were treated with $0.3 \%(\mathrm{v} / \mathrm{v})$ hydrogen peroxide and incubated for 30 min with $35 \%$ goat serum to block non-specific binding. The sections were incubated with primary antibody or $2 \%$ normal rabbit serum (VEGF and factor VIII) or $2 \%$ normal mouse serum (Ki67). Dilution and incubation times and temperatures for the different antibodies were: 1:200 for $120 \mathrm{~min}$ at room temperature for VEGF; 1:250 for $90 \mathrm{~min}$ at room temperature for factor VIII; and 1:40 for $3 \mathrm{~h}$ at $37^{\circ} \mathrm{C}$ for Ki67. The slides were subsequently incubated for 30 min with biotinylated goat anti-rabbit immunoglobulins (Vector Laboratories, Peterborough) or goat anti-mouse immunoglobulins (Vector Laboratories) for Ki67, diluted to 1:100 in phosphate buffered saline (PBS), or to 1:200 for Ki67. The slides were washed in PBS, treated with avidin-peroxidase complex (Vector Laboratories) and stained with $0.05 \%(\mathrm{w} / \mathrm{v}) 3,3^{\prime}$-diaminobenzidine containing $0.01 \%(\mathrm{v} / \mathrm{v})$ hydrogen peroxide. Counterstaining was performed with Meyer's haematoxylin and the sections were rinsed with Scott's tap water.

\section{Area of Von Willebrand factor VIII immunostaining}

The Quantimet image processing and analysis system 500 (Leica, Cambridge) was used to measure the area of immunostaining for factor VIII. Regions from the inner, middle and outer areas of the sections were randomly selected. Two sections and three fields per section were counted. The system was optimized for each individual section based on the density of the stain. The area used in the analysis was calibrated at $\times 200$ magnification. The area of factor VIII immunostaining for each group was expressed as mean \pm SEM per unit area. 


\section{Labelling index for cell proliferation}

Sections were examined at $\times 400$ magnification. The number of nuclei positively stained for Ki67 and the total number of nuclei were counted in two sections per animal and four fields per section, and the percentage of positively stained nuclei (label index) was calculated.

\section{Hormone assays}

Concentrations of progesterone and oestradiol were measured directly in follicular fluid using assays described previously (Corrie et al., 1981; Glasier et al., 1989; Law et al., 1992; Watson et al., 2000; Riley et al., 2001). Assay sensitivity was $0.5 \mathrm{ng} \mathrm{ml}^{-1}$ for progesterone and $8 \mathrm{pg} \mathrm{ml}^{-1}$ for oestradiol. Intra- and interassay coefficients of variation were 9.0 and $12.6 \%$, respectively, for progesterone, and 4.6 and $7.8 \%$, respectively, for oestradiol. Displacement curves produced by serial dilutions of follicular fluid and curves produced by addition of hormone to follicular fluid samples were parallel to the respective standard curves.

\section{Statistical analyses}

Hormone concentrations in follicular fluid from transitional and preovulatory follicles from the same mares, as well as follicle size, were compared by paired $t$ test. Hormone data were log-transformed before analysis. The area of staining for factor VIII and the proportion of cells staining positively for Ki67 in transitional and preovulatory follicles were compared using a paired $t$ test.

\section{Results}

Size of follicles at removal was not significantly different between the transitional $(33.8 \pm 2.3 \mathrm{~mm})$ and preovulatory $(34.1 \pm 1.5 \mathrm{~mm})$ groups. The colour of the walls of the transitional follicles was yellowish to pale pink, and that of the preovulatory follicles was orange to red. The concentration of oestradiol in follicular fluid was significantly lower $(P<0.01)$ in the transitional follicles $\left(345 \pm 112.3 \mathrm{ng} \mathrm{ml}^{-1}\right)$ than in the preovulatory follicles $\left(1063 \pm 169.2 \mathrm{ng} \mathrm{ml}^{-1}\right)$. Similarly, progesterone concentrations were significantly lower $(P<0.05)$ in transitional follicles $\left(6.2 \pm 1.7 \mathrm{ng} \mathrm{ml}^{-1}\right)$ than in preovulatory follicles $\left(33.6 \pm 12.8 \mathrm{ng} \mathrm{ml}^{-1}\right)$.

\section{Histological findings}

Both anovulatory and preovulatory follicles had a wellorganized layer of granulosa cells in contact with the basement membrane (Fig. 1). The granulosa cells appeared to be randomly distributed in the upper layers. There did not appear to be any difference in the thickness of the granulosa layers in anovulatory or preovulatory follicles, although there was some variability between follicles. Occasional mitotic nuclei were visible in both transitional and preovulatory follicles, and a few pycnotic nuclei were observed. The theca interna in preovulatory follicles comprised a thick layer of plump polyhedral cells with a pale nucleus and

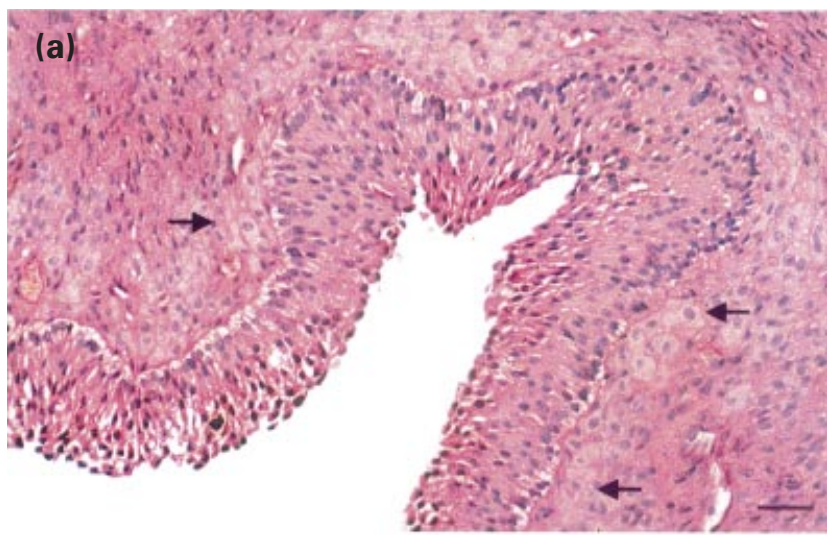

(b)

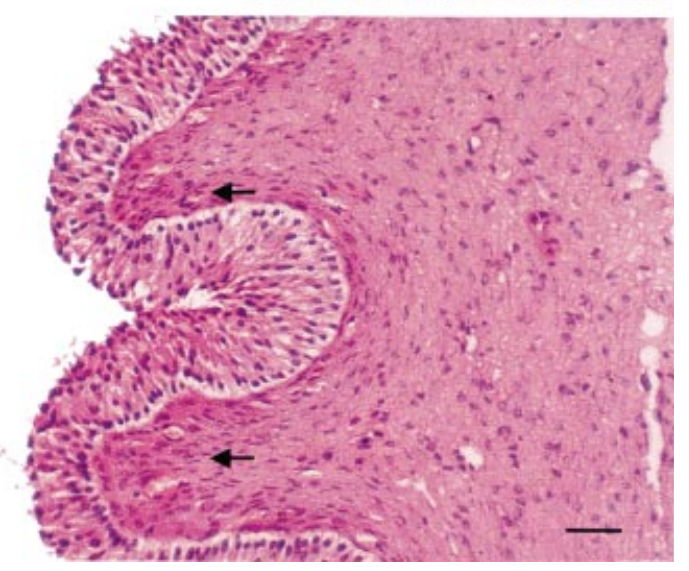

Fig. 1. Morphology of follicular walls from (a) a preovulatory and (b) a transitional anovulatory equine follicle. The theca interna in the transitional follicle is thin and lacks the plump polyhedral cells visible in the preovulatory follicle (arrows). Sections stained with haematoxylin and eosin. Scale bars represent $50 \mu \mathrm{m}$.

cytoplasm (Fig. 1a), whereas the theca layer of the anovulatory follicles was thin and poorly developed in most parts with only sparse foci of polyhedral cells (Fig. 1b). Most of the theca cells retained a fibroblast-type appearance with a spindle-shaped darkly staining nucleus.

\section{Immunohistochemical localization of VEGF, factor VIII and Ki67}

Immunostaining for VEGF was confined mainly to the theca interna. The granulosa layer remained mainly unstained, with a few scattered positively stained cells. In preovulatory follicles, the entire theca interna layer stained strongly and diffusely for VEGF (Fig. 2a). Immunostaining in the transitional follicles was scant, with patchy staining in the thin theca layer (Fig. 2b).

Immunostaining for factor VIII was confined to endothelial cells of blood vessels in the theca interna. The theca was well supplied with blood vessels in the preovulatory follicles, whereas the transitional follicles had a relatively avascular theca. A significantly larger $(P<0.05)$ area of 

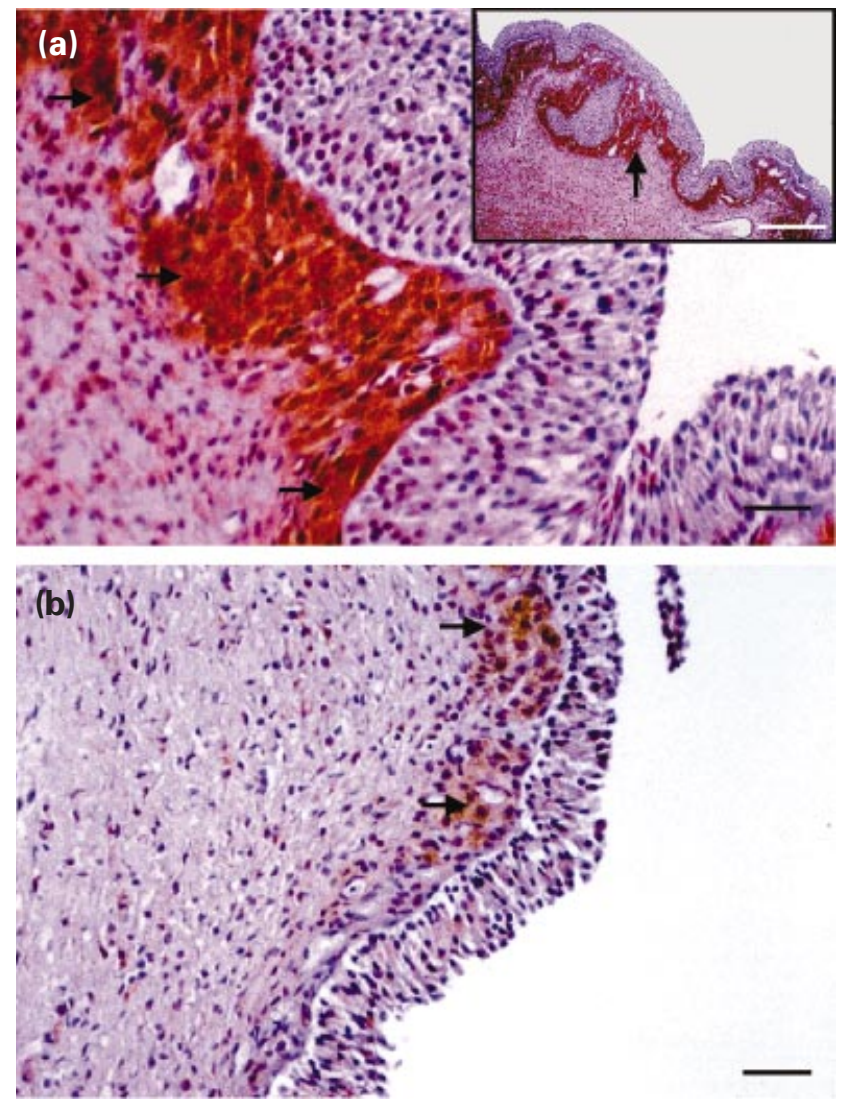

Fig. 2. Immunohistochemical staining for vascular endothelial growth factor (VEGF) in (a) a preovulatory follicle and (b) a transitional anovulatory equine follicle. Note the broad band of staining in the theca of the preovulatory follicle compared with the sparse staining in the transitional follicle (arrows). Inset shows low magnification of preovulatory follicle with intense staining in theca. Scale bars represent (a,b) $50 \mu \mathrm{m}$ and (inset in (a)) $500 \mu \mathrm{m}$.

tissue was stained for factor VIII in the preovulatory follicles than in the transitional follicles (Figs 3 and 4).

Positive staining for Ki67 was confined to cell nuclei and was frequently present in the granulosa cells and thecal endothelial cells of preovulatory follicles (Fig. 5a). No staining was visible in endothelial cells of transitional follicles and only occasional granulosa cells were stained (Fig. 5b). The difference in labelling index for Ki67 between preovulatory and transitional follicles was highly significant (Fig. 4).

Observations for immunohistochemical staining were consistent across all six animals studied. No positive immunostaining was observed in negative control sections (Fig. 6).

\section{Discussion}

The results of the present study show for the first time clear differences in morphology and vascularization between large follicles collected during spring transition (anovulatory) and the breeding season (preovulatory) from mares.
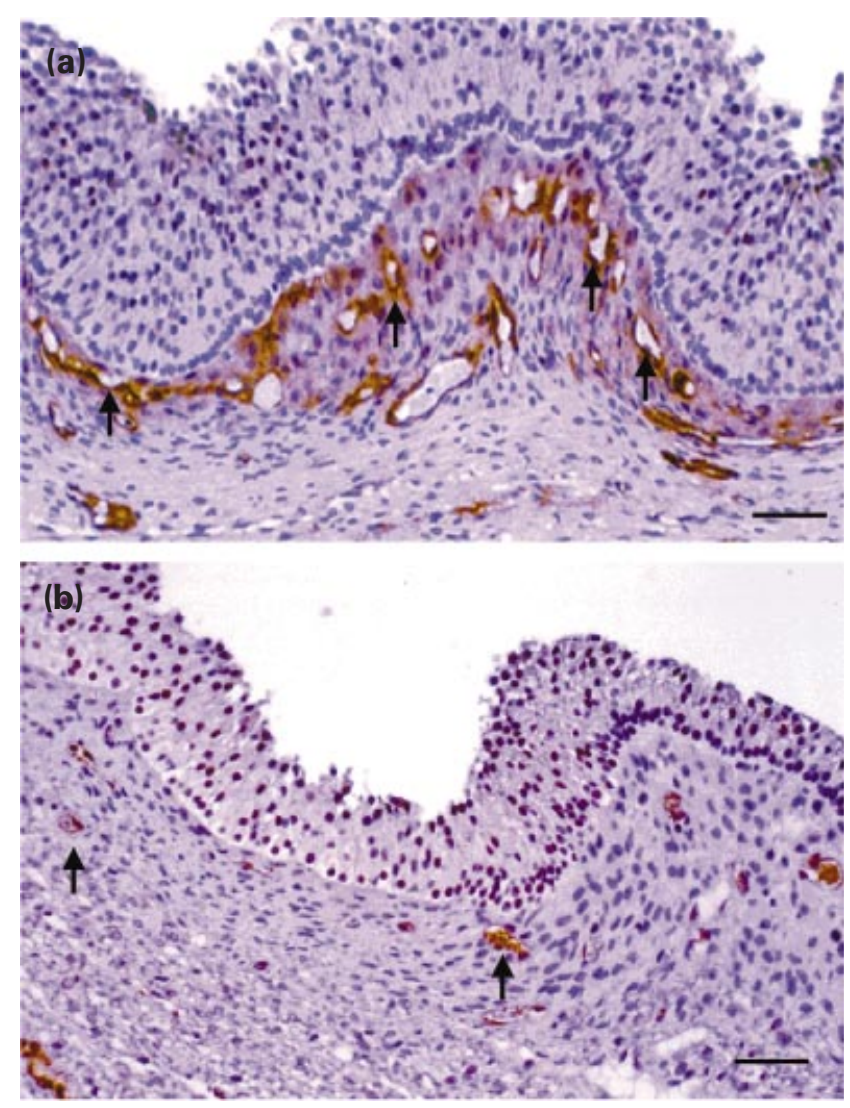

Fig. 3. Immunohistochemical staining for factor VIII in (a) a preovulatory follicle and (b) a transitional anovulatory equine follicle. Staining is confined to the theca (arrows). Scale bars represent $50 \mu \mathrm{m}$.

The major differences reported in this study, together with previously reported differences in circulating gonadotrophin concentrations, could play a key role in determining the subsequent fate of these two types of follicle.

A follicle diameter of approximately $35 \mathrm{~mm}$ was chosen because it is known that equine preovulatory follicles are responsive to exogenous gonadotrophin stimulation at this size and ovulate within $48 \mathrm{~h}$ (Duchamp et al., 1987). All of the follicles collected in the present study were still growing and were not regressing; this was confirmed by histological evaluation of granulosa and theca cell morphology. The morphological differences in the theca interna layer of the preovulatory and transitional follicles were marked. The preovulatory follicles had the characteristic plump polyhedral cells that have been described previously (Kenney et al., 1979; Kerban et al., 1999). It has been suggested that these cells have undergone luteinization (Kenney et al., 1979) and it is known that follicular progesterone concentrations increase during the preovulatory period in mares (Watson and Sertich, 1990). Furthermore, follicular progesterone concentrations were increased in the preovulatory follicles sampled in the present study. It has also been suggested that a thick theca layer may be essential in the growing pre- 


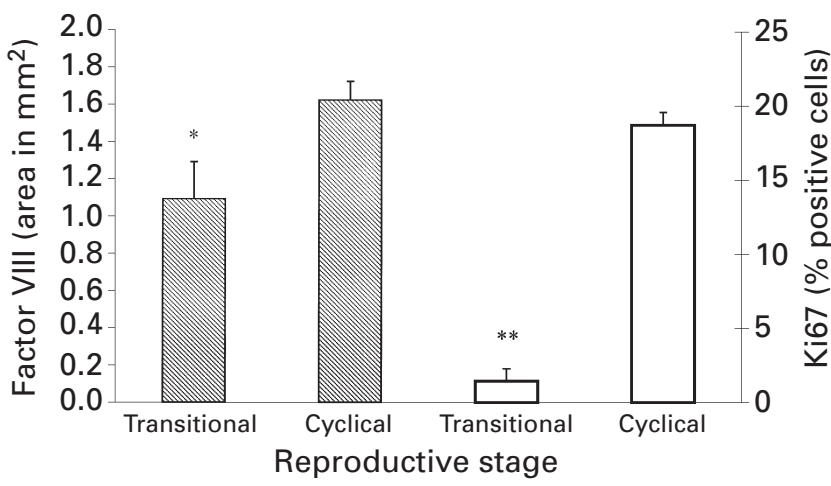

Fig. 4. Area of staining for factor VIII $(\mathbb{\mathbb { N }})$ and percentage of cells positive for $\mathrm{Ki} 67(\square)$ in transitional and cyclical preovulatory follicles from six mares. ${ }^{*} P<0.05$ and ${ }^{* *} P<0.001$ compared with cyclical value.

ovulatory follicle for provision of androgen substrate to maintain follicular oestradiol synthesis. Therefore, it seems likely that, as this layer is only poorly developed in transitional follicles, the lack of androgen substrate will contribute substantially to the low oestradiol concentrations measured in these follicles. Hence, the morphological findings of the present study explain the low steroidogenic capacity of incubated walls of transitional follicles (Davis and Sharp, 1991) and indicate strongly that the deficiency in thecal P450C17 suggested by Davis and Sharp (1991) is directly attributable to poor thecal development.

Poor vascularity, characterized by visibly pale follicular walls, has been reported to be a sign of atresia in equine follicles (Kenney et al., 1979; Mlodawska and Okolski, 1997; Pedersen, 2000). In the present study, the lining of transitional follicles was paler than that of preovulatory follicles. This observation was confirmed by immunostaining for factor VIII, which identifies endothelial cells. There was a significantly smaller area of factor VIII immunostaining in the theca of transitional follicles compared with preovulatory follicles; this does not necessarily mean that there was a greater number of individual blood vessels, as the same vessel may intersect the plane of the section any number of times. However, the results of the present study indicate strongly that there is increased vascularity in the preovulatory follicles compared with transitional follicles as a result of increased numbers of vessels, increased size of the vessels or increased tortuosity of the vessels, or a combination of these factors. Furthermore, the transitional follicles contained very little VEGF, which is important in promoting angiogenesis, whereas VEGF appeared to be abundant in the preovulatory follicles. VEGF also has the ability to increase the permeability of the microvasculature (Murohara et al., 1998). Thus, in preovulatory follicles, the richer blood supply in combination with increased permeability of blood vessels will allow increased provision of oxygen, nutrients and substrates, as well as circulating gonadotrophins, which are essential for follicular health, growth and steroidogenesis. In addition, the rich blood

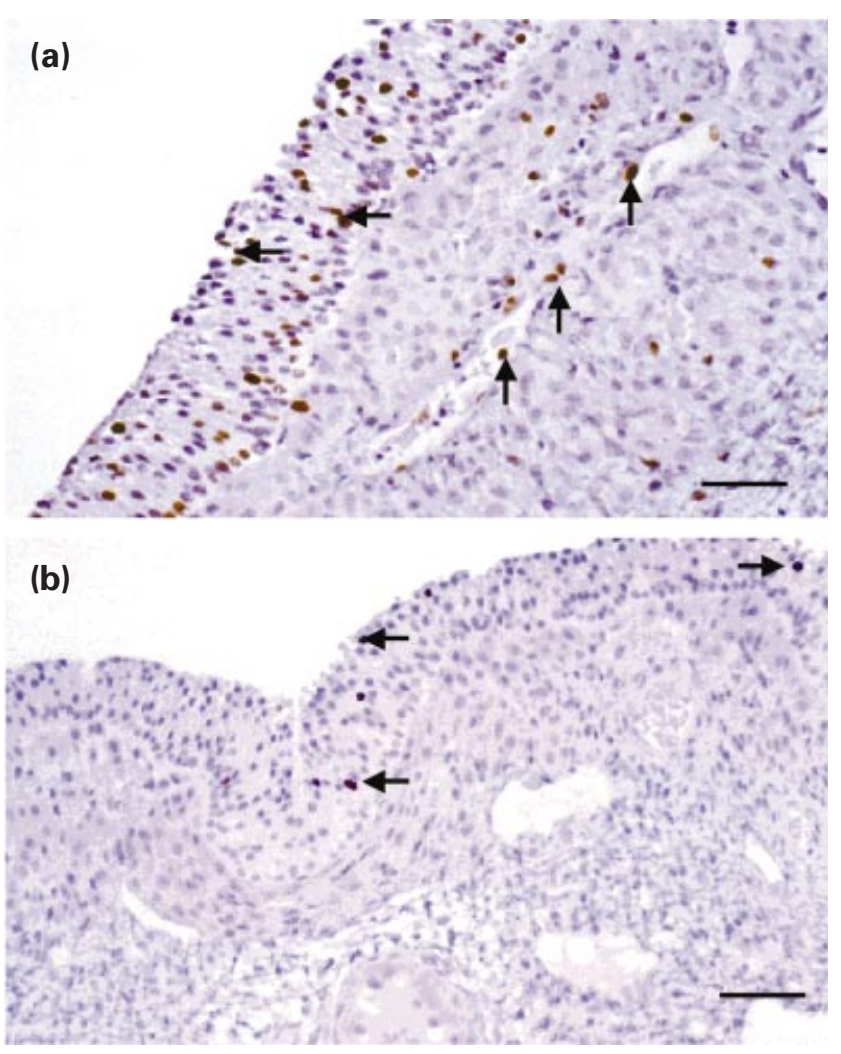

Fig. 5. Immunohistochemical staining for Ki67 in (a) a preovulatory follicle and (b) a transitional equine follicle. Note positive nuclear staining in granulosa cells (horizontal arrows) and in endothelial cells in the preovulatory follicles only (vertical arrows). Scale bars represent $40 \mu \mathrm{m}$.

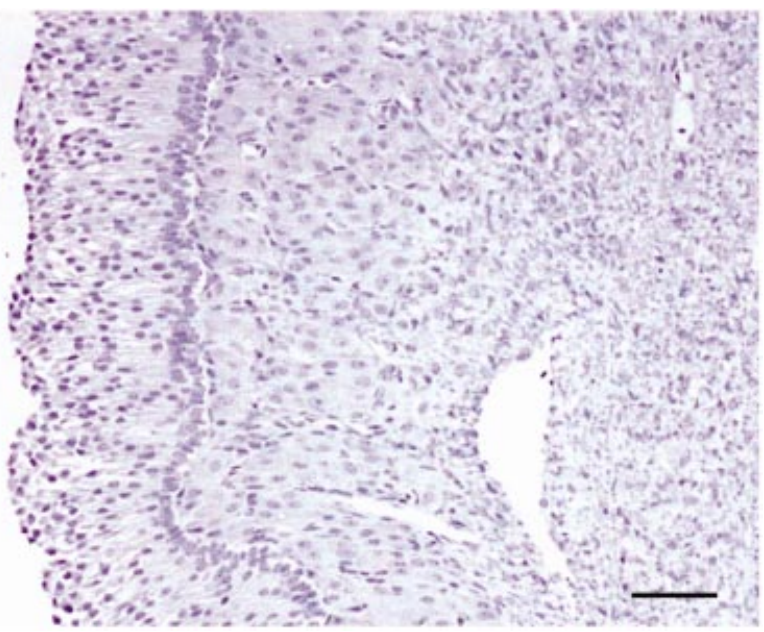

Fig. 6. Negative control section of an equine preovulatory follicle stained for Ki67 in which the primary antibody was substituted with $2 \%$ normal mouse serum. Negative control sections for the other antigens similarly lacked positive staining. Scale bar represents $50 \mu \mathrm{m}$.

supply to preovulatory follicles will allow more follicular steroids and other hormones to leave the follicular fluid and access the circulation. 
The VEGF protein was clearly present in the thecal cells of equine follicles, which is similar to human follicles (Gordon et al., 1996; Yamamoto et al., 1997). VEGF protein and mRNA encoding VEGF have been identified in both granulosa and theca cells from follicles of cows (Berisha et al., 2000) and pigs (Barboni et al., 2000). Isolated granulosa cells from various species secrete VEGF in culture (Christenson and Stouffer, 1997; Hazzard et al., 1999; Barboni et al., 2000). These differences may in part reflect species differences or disparity in stages of follicle maturity at the time of collection, but may also indicate that VEGF is being produced in the granulosa cells and that the protein then passes to the theca layer where the blood vessels are located. Post-transcriptional regulation of VEGF production by gonadotrophins may take place in periovulatory follicles (Hazzard et al., 1999).

The growth of new blood vessels can also be monitored by measuring proliferation of endothelial cells (JablonkaShariff et al., 1993; Rodger et al., 1997). Immunohistochemical detection of the proliferation marker Ki67 has been used previously as a monitor of mitotic activity in equine endometrium (Gerstenberg et al., 1999). Cells with the morphology of endothelial cells that stained positively for Ki67 were present only in the theca of preovulatory follicles, which is indicative of active proliferation of blood vessels in these follicles. Many of the granulosa cells in these follicles were also positively stained, whereas staining was infrequent in the granulosa of the transitional follicles, indicating active cell division in the preovulatory follicles in contrast to the transitional follicles. In the marmoset corpus luteum, it appears that luteal cells that stain positively for Ki67 do not co-label with the steroidogenic cell marker $3 \beta$ HSD (Young et al., 2000), indicating that steroidogenic cells may not produce steroid hormones and express cell cycle antigens simultaneously. It is not known whether this is also true in the follicle, but the preovulatory follicles in the present study with high proliferation indices were markedly more steroidogenically active than the transitional follicles. It has been shown that activation of VEGF production is more dependent on the dynamic status of the follicle and its growth rate than on its diameter (Barboni et al., 2000). This finding correlates well with the high degree of proliferative activity in the preovulatory follicles in the present study.

The low vascularization in the transitional follicles in the present study, together with the low proliferative index, low VEGF protein content and follicular steroids are consistent with early follicular atresia, although this was not evident histologically. As seen in the present study in equine follicles, endothelial cell proliferation has been strongly correlated with expression of VEGF in theca cells during follicle growth (Yamamoto et al., 1997). Follicle health depends on the presence of a rich network of capillaries in the innermost part of the thecal wall, so that oxygen and nutrients can be transported into the follicle, particularly at the cumulus-oocyte complex. Early signs of atresia are characterized by disappearance of this inner vascular layer
(Hay et al., 1976). Hypoxia is commonly implicated in stimulation of VEGF in most tissues, but in ovarian cells, a relationship has been shown between gonadotrophin stimulation of cultured luteinized granulosa cells and VEGF production (Christenson and Stouffer, 1997; Hazzard et al., 1999). Other studies have shown in vivo that the intense angiogenesis in the early primate corpus luteum is dependent on gonadotrophin stimulation of the luteal cells (Dickson and Fraser, 2000) and VEGF concentrations in follicular fluid from prepubertal gilts increase after eCG and hCG treatment (Barboni et al., 2000). As follicle health and growth are also dependent on gonadotrophin stimulation, it is likely that the low circulating concentrations of $\mathrm{LH}$, characteristic of the transitional breeding season (Freedman et al., 1979), failed to stimulate adequate production of angiogenic factors, including VEGF. Other trophic hormones such as growth hormone, which is known to be low in mares during seasonal anoestrus (Aurich et al., 1999) and is involved in follicle growth and viability (Kirkwood et al., 1990), may also be involved. The low concentrations of angiogenic factors then led to poor thecal vascularization and vascular permeability, both of which are essential for trophic support of the actively dividing follicular cells. In turn, poor vascularity will contribute to inadequate delivery of gonadotrophins and other trophic factors to the follicle to sustain development. Therefore, in these mares, the low concentrations of thecal VEGF could result in failure of further development and subsequent atresia of transitional follicles. In primates, VEGF production has been implicated in follicle selection during the menstrual cycle (Ravindranath et al., 1992). From the results of the present study it appears likely that VEGF could also be a key factor in regulating gonadotrophin-dependent follicular growth in equine preovulatory follicles.

It is possible to draw three main conclusions on the differences between transitional and preovulatory follicles: (i) the histological morphology of these two types of follicle is clearly different: the thecal layer is only poorly developed in transitional follicles and the proliferative index of the granulosa cells is markedly depressed in transitional follicles; (ii) thecal vascularization is sparse in transitional follicles in association with the absence of proliferative activity in the vascular endothelial cells; and (iii) VEGF, one of the main angiogenic factors, is present in abundance in the theca of preovulatory, but not transitional, follicles. These inter-related factors could explain the low steroidogenic capacity of transitional follicles and why these follicles fail to progress to ovulation during the spring anovulatory period in mares.

This study was funded by the Horserace Betting Levy Board (project number 666). M. O. Al-zi'abi was in receipt of a studentship from Alba'ath University, Syria. The authors would like to thank O. Sheerin for assistance with the ovarian palpations and S. Melling for taking excellent care of the research mares. Some of the data contained in this paper were presented at the Eighth International Symposium on Equine Reproduction, Colorado, 2002. 


\section{References}

Aurich C, Gerlach T, Aurich JE and Parvizi N (1999) Seasonal variation and opioidergic regulation of growth hormone release in cyclic, ovariectomized, and pregnant pony mares Biology of Reproduction 61 1575-1580

Aurich C, Parvizi N, Brunklaus D, Hoppen H-O and Aurich JE (2000) Opioidergic and dopaminergic effects on $\mathrm{LH}$ and prolactin release in Pony mares at different times of the year Journal of Reproduction and Fertility Supplement $\mathbf{5 6}$ 195-203

Barboni B, Turriani M, Galeati G, Spinaci M, Bacci ML, Forni $M$ and Mattioli M (2000) Vascular endothelial growth factor production in growing antral pig follicles Biology of Reproduction 63 858-864

Berisha B, Schams D, Kosmann M, Amselgruber W and Eispanier R (2000) Expression and localisation of vascular endothelial growth factor and basic fibroblastic growth factor during the final growth of bovine ovarian follicles Journal of Endocrinology 167 371-382

Christenson LK and Stouffer RL (1997) Follicle-stimulating hormone and luteinizing hormone/chorionic gonadotropin stimulation of vascular endothelial growth factor production by macaque granulosa cells from pre- and periovulatory follicles Journal of Clinical Endocrinology and Metabolism 82 2135-2142

Corrie JET, Hunter WM and Macpherson JS (1981) A strategy for radioimmunossay of plasma progesterone with the use of a homologous site ${ }^{125}$ I-labelled radioligand Clinical Chemistry 27 594-599

Davis SD and Sharp DC (1991) Intra-follicular and peripheral steroid characteristics during vernal transition in the pony mare Journal of Reproduction and Fertility Supplement 44 333-340

Dickson SE and Fraser HM (2000) Inhibition of early luteal angiogenesis by gonadotropin-releasing hormone antagonist treatment in the primate Journal of Clinical Endocrinology and Metabolism 85 2339-2344

Duchamp G, Bour B, Combarnous Y and Palmer E (1987) Alternative solutions to hCG in induction of ovulation in the mare Journal of Reproduction and Fertility Supplement 35 221-228

Dvorak HF, Brown LF, Detmar M and Dvorak AM (1995) Vascular permeability factor/vascular endothelial growth factor, microvascular hyperpermeability, and angiogenesis American Journal of Pathology 146 1029-1039

Fitzgerald BP and Mellbye LB (1988) Effect of administration of an $\alpha_{2}$-adrenenrgic agonist, xylazine, on pulsatile gonadotrophin secretion in anoestrous horse mares Journal of Reproduction and Fertility $\mathbf{8 4}$ 693-700

Freedman LJ, Garcia MC and Ginther OJ (1979) Influence of ovaries and photoperiod on reproductive function in the mare Journal of Reproduction and Fertility Supplement 27 79-86

Gerstenberg C, Allen WR and Stewart F (1999) Cell proliferation patterns in the equine endometrium throughout the non-pregnant reproductive cycle Journal of Reproduction and Fertility 116 167-175

Ginther OJ (1990) Folliculogenesis during the transitional period and early ovulatory season in mares Journal of Reproduction and Fertility $\mathbf{9 0}$ $311-320$

Glasier AF, Irvine DS, Wickings EJ, Hillier SG and Baird DT (1989) A comparison of the effects on follicular development between clomiphene citrate, its two separate isomers and spontaneous cycles Human Reproduction 4 252-256

Gordon JD, Mesiano S, Zaloudek CJ and Jaffe RB (1996) Vascular endothelial growth factor localization in human ovary and Fallopian tubes: possible role in reproductive function and ovarian cyst Formation Journal of Clinical Endocrinology and Metabolism 81 353-359

Hay MF, Cran DG and Moor RM (1976) Structural changes occurring during atresia in sheep ovarian follicles Cell and Tissue Research 169 515-529

Hazzard TM, Molskness TA, Chaffin CL and Stouffer RL (1999) Vascular endothelial growth factor (VEGF) and angiopoietin regulation by gonadotrophin and steroids in macaque granulosa cells during the periovulatory interval Molecular Human Reproduction 5 1115-1121

Jablonka-Shariff A, Grazul-Bilska AT, Redmer DA and Reynolds LP (1993) Growth and cellular proliferation of ovine corpora lutea throughout the estrous cycle Endocrinology 133 1871-1879
Kashida S, Sugino N, Takiguchi S, Karube A, Takayama H, Yamagata Y Nakamura Y and Kato H (2001) Regulation and role of vascular endothelial growth factor in the corpus luteum during mid-pregnancy in rats Biology of Reproduction 64 317-323

Kenney RM, Condon W, Ganjam VK and Channing C (1979) Morphological and biochemical correlates of equine ovarian follicles as a function of their state of viability or atresia Journal of Reproduction and Fertility Supplement 27 163-171

Kerban A, Dore M and Sirois J (1999) Characterization of cellular and vascular changes in equine follicles during hCG-induced ovulation Journal of Reproduction and Fertility 117 115-123

Kirkwood RN, Thacker PA, Guedo BL and Laarveld B (1990) Effect of exogenous growth hormone during the follicular phase on hCG binding by porcine luteal tissue Canadian Journal of Animal Science 70 719-721

Law AS, Baxter G, Logue DN, O'Shea T and Webb R (1992) Evidence for the action of bovine follicular fluid factor(s) other than inhibin in suppressing follicular development and delaying oestrus in heifers Journal of Reproduction and Fertility 96 603-616

Mlodawska W and Okolski A (1997) Equine oocyte-cumulus morphology as affected by follicular size Equine Veterinary Journal Supplement $\mathbf{2 5}$ $38-42$

Murohara T, Horowitz JR, Silver M, Tsurumi Y, Chen D, Sullivan A and Isner JM (1998) Vascular endothelial growth factor/vascular permeability factor enhances vascular permeability via nitric oxide and prostacyclin Circulation 97 99-107

Pedersen HG (2000) Follicular Growth and Atresia in the Mare PhD Thesis, University of Edinburgh

Ravindranath N, Little-Ihrig L, Phillips HS, Ferrara N and Zeleznik AJ (1992) Vascular endothelial growth factor messenger ribonucleic acid expression in the primate ovary Endocrinology $1254-260$

Richards IS (1980) Maturation of ovarian follicles: action and interaction of pituitary and ovarian hormones on follicular cell differentiation Physiological Reviews 60 51-89

Riley SC, Gibson AH, Leask R, Mauchline DJW, Pedersen HG and Watson ED (2001) Secretion of matrix metalloproteinase-2 and -9 and tissue inhibitor of metalloproteinases into follicular fluid during follicle development in the equine ovary Reproduction 121 553-560

Rodger FE, Young FM, Fraser HM and Illingworth PJ (1997) Endothelial cell proliferation follows the mid-cycle luteinizing hormone surge, but not human chorionic gonadotrophin rescue, in the human corpus luteum Human Reproduction 12 1723-1729

Seamans KW and Sharp DC (1982) Changes in equine follicular aromatase activity during sexual recrudescence Journal of Reproduction and Fertility Supplement 32 225-233

Sharp DC and Davis SD (1993) Vernal transition. In Equine Reproduction pp 133-143 Eds AO McKinnon and JL Voss. Lea and Febiger, Philadelphia

Sharp DC, Grubaugh WR, Weithenauer J, Davis SD and Wilcox CJ (1991) Effect of steroid administration on pituitary luteinizing hormone and follicle-stimulating hormone in ovariectomized pony mares in the early spring: pituitary responsiveness to gonadotropin-releasing hormone and pituitary gonadotropin content Biology of Reproduction 44 983-990

Silvia PJ, Squires EL and Nett TM (1987) Pituitary responsiveness of mares challenged with $\mathrm{GnRH}$ at various stages of the transition into the breeding season Journal of Animal Science 64 790-796

Toutges MJ, Grazul-Bilska AT, Kraft KC, Kirsch JD, Redmer DA and Reynolds LP (2000) Effects of luteinizing hormone (LH) and oxygen $\left(\mathrm{O}_{2}\right)$ on vascular endothelial growth factor (VEGF) mRNA expression by ovine thecal and granulosa cells Biology of Reproduction 62 Supplement 1288 (Abstract)

Turner DD, Garcia MC and Ginther OJ (1979) Follicular and gonadotropic changes throughout the year in pony mares American Journal of Veterinary Research 40 1694-1700

Watson ED and Sertich PL (1990) Secretion of prostaglandins and progesterone by cells from corpora lutea of mares Journal of Reproduction and Fertility $88223-229$

Watson ED, Pedersen HG, Thomson SRM and Fraser HM (2000) Control of follicular development and corpus luteum function in the mare: effects of a GnRH antagonist Theriogenology 54 599-609 
Yamamoto S, Konishi I, Tsuruta Y et al. (1997) Expression of vascular endothelial growth factor (VEGF) during folliculogenesis and corpus luteum formation in the human ovary Gynecology and Endocrinology $11371-381$

Young FM, Rodger FE, Illingworth PJ and Fraser HM (2000) Cell proliferation and vascular morphology in the marmoset corpus luteum Human Reproduction 15 557-566

Zeleznick AJ, Shuler HM and Reichert LE, Jr (1981) Gonadotropin-binding site in the Rhesus monkey ovary: role of the vasculature in the selective distribution of human chorionic gonadotropin to the preovulatory follicle Endocrinology 109 356-362

Received 28 August 2001.

First decision 29 October 2001.

Revised manuscript received 18 February 2002.

Accepted 4 March 2002. 